\title{
Impact of forest vegetation on soil characteristics: a correlation between soil biological and physico-chemical properties
}

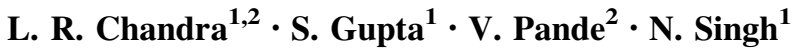

Received: 2 February 2016/Accepted: 24 August 2016/Published online: 1 September 2016

(c) The Author(s) 2016. This article is published with open access at Springerlink.com

\begin{abstract}
Temperate and dry deciduous forest covers major portion of terrestrial ecosystem in India. The two forest types with different dominant tree species differ in litter quality and root exudates, thereby exerting speciesspecific impact on soil properties and microbial activity. This study aims to examine the influence of forest type or dominant tree species on soil physico-chemical properties and its relationship with microbial characters in temperate and dry deciduous forest types. We assessed soil physicochemical properties among five different sites located within the selected forest stand covered by different dominant species. The soil microbial biomass carbon (MBC), nitrogen (MBN) and phosphorous (MBP) were recorded high in oak soil, i.e., the MBC/TOC ratio was significantly higher in dry deciduous forest. Basal respiration was recorded highest at oak-mixed soil while $\mathrm{qCO}_{2}$ was comparatively high in oak soil. Temperate forest displayed the highest MBC/MBN ratio, while dry deciduous forest had the highest $\mathrm{MBC} / \mathrm{MBP}$ ratio. Moreover, the $\mathrm{MBN} / \mathrm{TN}$ ratio was found high in dry deciduous forest, whereas MBP/TP ratio was high in temperate forest. Additionally, the enzyme activities were significantly higher in an oakmixed soil among all the sites. The results displayed that the soil microbial characters and soil physico-chemical
\end{abstract}

N. Singh

nanditasingh8@yahoo.co.in

L. R. Chandra

lovychandra09@gmail.com

1 Plant Ecology and Environmental Science Division, CSIR-National Botanical Research Institute, Rana Pratap Marg, Lucknow, Uttar Pradesh 226 001, India

2 Department of Biotechnology, Bhimtal Campus, Kumaun University, Nainital, Uttarakhand 263136, India uniqueness are interrelated, and were significantly influenced by specific forest type and climatic variables.

Keywords Soil microbial biomass - Soil quality · Forest ecosystem $\cdot$ Nutrient cycle $\cdot$ Enzyme activity

\section{Introduction}

Soil microorganisms are important components of terrestrial ecosystems because they play an important role in intrinsic phenomena like nutrient cycle and ecosystem functioning which directly involve in maintaining soil fertility and its structure. Soil microbial biomass formation is the living portion of soil organic matter, responsible for the decomposition and mineralization of the organic matter fraction that acts both as a sink and a source of nutrient which become available during the turnover of microbial biomass (Chen et al. 2005). Therefore, the information regarding the factors that control the soil microorganism and microbial biomass is fundamental to a sustainable environmental system. The accessibility and uptake of nutrients is directly proportional to the living component of the given soil niche. Thus, soil microbial processes strongly regulate the stability, fertility and functioning of ecosystems and used to assess the soil excellence among different vegetations (Fierer et al. 2003).

Due to various effects, the assessment of soil quality is relatively complicated. A specific combination of physicochemical and biological factors is required for maintaining the soil strength. Understanding of these features supports in knowing the soil health. The major portion of terrestrial ecosystems is covered by forest land. Soil microbes regulate the decomposition rate, organic matter content of soil and the overall biogeochemical processes that govern the 
productivity of forest ecosystems (Six et al. 2004; Noguez et al. 2008) and in turn, the soil physico-chemical properties of the given forest type control the microbial biomass as well as their activity. Forest stands covered with different tree species; differ in litter quality and root exudates. This difference ultimately generates a divergence in soil properties and may influence the soil microbial community.

Natural forests that occur all over the world are formed through natural regeneration following stand-replacing disturbances by anthropogenic activities or by extreme natural events (Yang et al. 2010; Wang and Yang 2007). Approximately $30 \%$ of total land area is covered by forest (boreal, temperate and tropical forest) (Holden and Treseder 2013). These forests are the source of global terrestrial carbon in which temperate forest ecosystem plays a major role in carbon sequestration from increasing atmospheric carbon dioxide, as it covers the major portion of terrestrial land (Myneni et al. 2001). It has been predicted that naturally regenerated forest stands are generally superior to plantations in nutrient cycling and soil quality (Burton et al. 2007), but some conflicting experimental results suggest that variations in soil microbial biomass probably depend on the specific forest ecosystems and climatic factors.

Various studies have been given to understand interrelationship between the tree species, soil microbial and physico-chemical properties of forest soil. Further, studies undertaken on varied forest soils confirm that various biotic and abiotic factors influence the microbial biomass, composition and activity (Landesman and Dighton 2011). Still, the information is limited as several factors control this interrelationship in the forest ecosystem. Consequently, the present study has been undertaken in different natural forest stands from dry deciduous and temperate region of North-India that contains a wide range of biodiversity. The main aim of the study is to hypothesize the impact of the specific forest type of biological properties that mainly include the difference in soil microbial biomass, respiration and soil enzymes activity, and interpret the correlation between soil biological and physico-chemical characteristics.

\section{Materials and methods}

\section{Study sites, soil sampling and pretreatment}

The study has been undertaken in two different natural forest types of India. The selected forest types were located in Nainital and Sonbhadra district of Uttarakand and Uttar Pradesh states, respectively (Fig. 1). The two forest types are classified into dry deciduous and temperate forest. The Shorea robusta (sal) is the dominant species of Sonbhadra

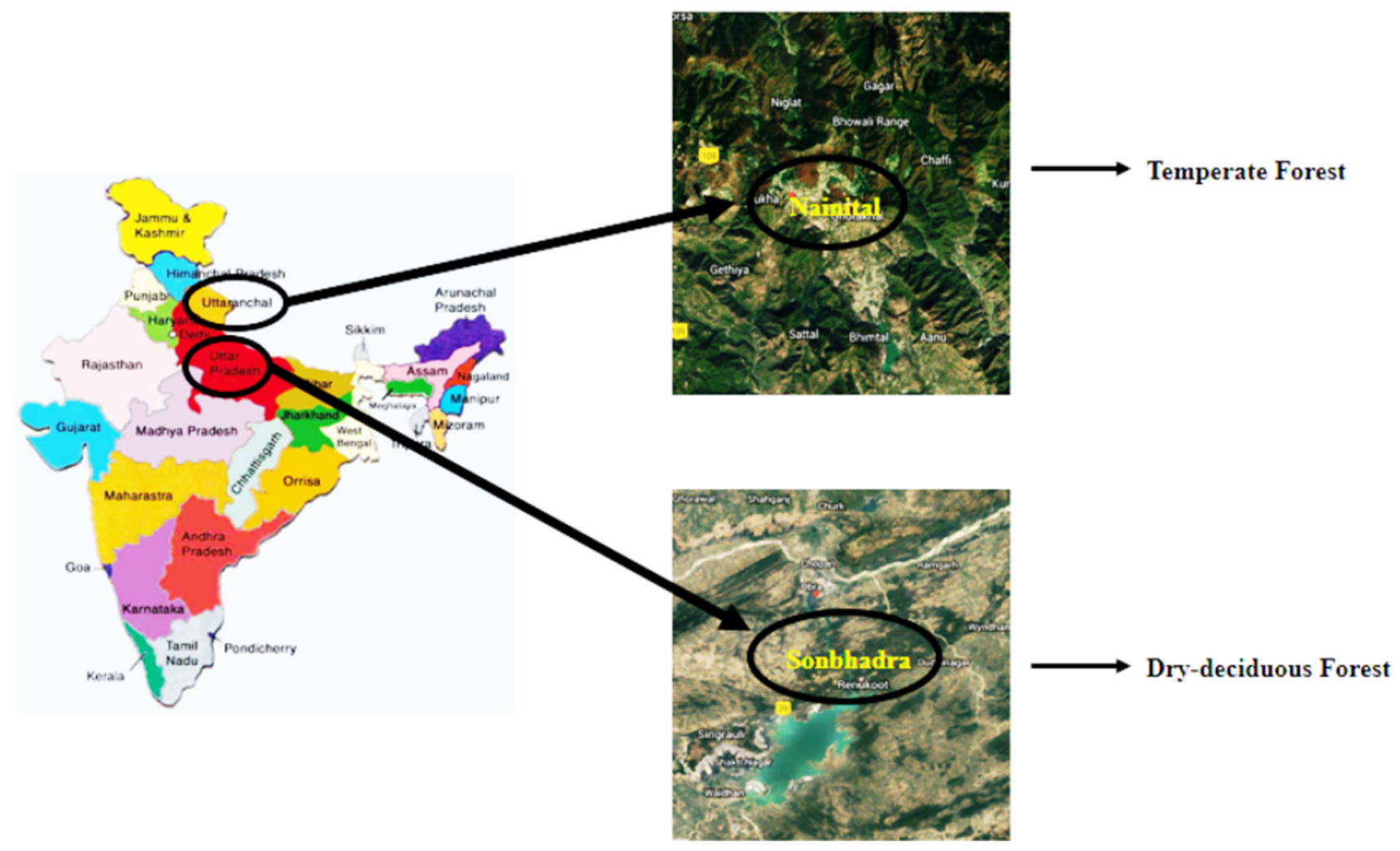

Fig. 1 Selected area and forest types. Source: Google Map 
forest, dry deciduous in nature and is considered as one of the best Sal forests of India, followed by Diospyros melanoxylon, Lagerstroemia parviflora, Anogeissus latifolia, Bridelia retusa, Hardwickia binata, Mallotus philippensis, Buchanania lanzan and Terminalia elliptica as codominant species. Similarly, temperate forest sites of Nainital district comprise of three dominant plant communities, one dominated by Pinus roxburghii (pine) and other two by Quercus floribunda and Quercus leucotrichophora (oak), the other co-dominant plant communities are Quercus semecarpifolia, Rhododendron arboretum, Myrica esculenta, Berberis asiatica and Urtica parviflora. All the stands share different forest age and soil type. A total of five stands were selected among the two forest types. The two stands of dry deciduous forest are selected on the basis of vegetation covered. One stand is dominated by sal (Shorea robusta) vegetation while other stand is salmixed vegetative stand. Similarly, the three selected stands located in temperate region are dominated by pine (Pinus roxburghii), oak (Quercus leucotrichophora) and oakmixed vegetation, respectively. During the study period, the minimum temperature ranged from 6 to $29^{\circ} \mathrm{C}$ and maximum temperature varied from 28 to $42{ }^{\circ} \mathrm{C}$ in the forest of the dry deciduous region. Whereas, the minimum temperature in the forest of temperate region is recorded as -3 to $12{ }^{\circ} \mathrm{C}$ and maximum range is $18-30{ }^{\circ} \mathrm{C}$. The minimum and maximum temperature was recorded during the month of January and June, respectively. Additionally, the recorded average annual rainfall for dry deciduous and temperate forest was 73.1 and $151.9 \mathrm{~mm}$, respectively. The physiographic factors and the vegetation details of the selected stands of the two forest types are outlined in Table 1.

The soil samples were collected within the rhizospheric zone of the existing tree species of selected stands in October 2013 , to evaluate the effect of forest types on soil microbial properties. At each selected stand, the samples were taken within 0-10 cm layer after removing the litter as most of the microbial biomass is present in the surface layer. The stands were demarcated into five plots $(5 \mathrm{~m} \times 5 \mathrm{~m})$ and the approximate distance in between the plots was about $5 \mathrm{~km}$. Soil samples were collected randomly from six different locations of each plot and a total of thirty samples per stand which were further pooled to form five composite samples per stand. The soil samples were placed in plastic bags and taken to the laboratory. The soil samples were air dried and homogenised manually. Further, the soils were seived using $2 \mathrm{~mm}$ mesh to perform physico-chemical analysis. A subsample of each soil was sieved and stored at $4{ }^{\circ} \mathrm{C}$.

\section{Physico-chemical analysis of soil}

Soil $\mathrm{pH}$ and electrical conductivity (EC) were obtained using soil:distilled water (1:2.5). Soil texture was done by hydrometric method. Among other parameters water holding capacity (WHC), bulk density (BD), particle density (PD) and porosity were analyzed by the method described by Black et al. (1965). Total organic carbon was estimated using Walkley and Black (1934) method. Available and total nitrogen (AN and TN) was assessed using the specified method given by Stanford and smith (1978) and Kjeldahl nitrogen (Kjeltech analyzer) (Jackson 1958). Available and total phosphorous were estimated by Olsen method (Olsen et al. 1983) and stannous chloride method given by Sparling et al. (1985) followed by hot plate digestion in $\mathrm{HNO}_{3}: \mathrm{HClO}_{3}(3: 1)$ at $180{ }^{\circ} \mathrm{C}$ for $6 \mathrm{~h}$ was used. Available sodium, potassium and calcium concentration were measured using the flame photometric method (systronics-128) (Jackson 1958) followed by extraction with $2 \%$ ammonium acetate buffer. Ammonical nitrogen $\left(\mathrm{NH}_{4}{ }^{+}-\mathrm{N}\right)$ and nitrate nitrogen $\left(\mathrm{NO}_{3}{ }^{-}-\mathrm{N}\right)$ were analyzed by Phenate method (APHA 1985) and phenol disulphonic

Table 1 Environmental characteristic of the selected stands

\begin{tabular}{|c|c|c|c|c|c|}
\hline Forest types & Selected stands & Dominant plant species & Longitude & Latitude & Elevation (m) \\
\hline \multirow[t]{2}{*}{ Dry deciduous forest } & Sal stand & $\begin{array}{l}\text { Shorea robusta, Lagerstroemia parviflora, } \\
\text { Diospyros melanoxylon, Terminalia elliptica }\end{array}$ & E $083^{\circ} 6^{\prime} 21.2^{\prime \prime}$ & $\mathrm{N} 24^{\circ} 18^{\prime} 59.7^{\prime \prime}$ & 265 \\
\hline & Sal-mixed stand & $\begin{array}{l}\text { Shorea robusta, Anogeissus latifolia, Diospyros } \\
\text { melanoxylon, Bridelia retusa, Buchanania lanzan, } \\
\text { Hardwickia binata, Mallotus philippensis, } \\
\text { Buchanania lanzan }\end{array}$ & E $083^{\circ} 6^{\prime} 18.2^{\prime \prime}$ & N $24^{\circ} 17^{\prime} 59.7^{\prime \prime}$ & 258 \\
\hline \multirow[t]{3}{*}{ Temperate forest } & Pine stand & $\begin{array}{l}\text { Pinus roxburghii, Rhododendron arboretum, } \\
\text { Indigofera heterantha, Viburnum cotinifolium }\end{array}$ & E $079^{\circ} 32^{\prime} 22.9^{\prime \prime}$ & $\mathrm{N} 29^{\circ} 23^{\prime} 24.4^{\prime \prime}$ & 1822 \\
\hline & Oak-mixed stand & $\begin{array}{c}\text { Quercus leucotrichophora, Quercus floribunda, } \\
\text { Quercus semecarpifolia, Urtica parviflora, } \\
\text { Rhododendron arboretum, Berberis asiatica }\end{array}$ & E $079^{\circ} 31^{\prime} 43.9^{\prime \prime}$ & N $29^{\circ} 21^{\prime} 20.9^{\prime \prime}$ & 1305 \\
\hline & Oak stand & $\begin{array}{l}\text { Quercus leucotrichophora, Quercus floribunda, } \\
\text { Rhododendron arboretum, Myrica esculenta }\end{array}$ & E $079^{\circ} 33^{\prime} 08.3^{\prime \prime}$ & N $29^{\circ} 21^{\prime} 15.9^{\prime \prime}$ & 1333 \\
\hline
\end{tabular}


acid method (Jackson 1958), after the extraction of soil samples in $\mathrm{KCl}$ and $\mathrm{CaSO}_{4}$ solution, respectively.

\section{Soil microbial biomass $\mathbf{C}, \mathbf{N}$ and $\mathbf{P}$}

Soil microbial biomass carbon (MBC), nitrogen (MBN) and phosphorous (MBP) were estimated using the chloroform fumigation-extraction method given by Brookes et al. (1982, 1985) and Vance et al. (1987) using $\mathrm{K}_{2} \mathrm{SO}_{4}(0.5 \mathrm{M})$ and $\mathrm{NaHCO}_{3}(0.5 \mathrm{M})$ as extracting solution in $\mathrm{MBC}, \mathrm{MBN}$ and MBP, respectively. For MBC, the extract was filtered with Whatman No. 42 filter paper and the filtrate was analyzed by potassium dichromate method explained by Vance et al. (1987). For MBN, the filtrate was processed using Kjeldahl method. Similarly, for MBP, the filtrate was analyzed using Olsen method (Olsen et al. 1983). The final MBC, MBN, and MBP were calculated from differences between fumigated and non-fumigated samples with a conversion factor of $0.33,0.54$ and 0.40 for $\mathrm{MBC}, \mathrm{MBN}$ and MBP, respectively. Microbial quotient, i.e., the percentage of organic $\mathrm{C}$ presently as microbial $\mathrm{C}$ is calculated as the ratio of microbial biomass carbon to total organic carbon (MBC/TOC).

\section{Soil basal respiration}

Soil respiration was quantified using alkali absorption method using the moist soil sample. The $25 \mathrm{~g}$ of moist soil samples were incubated in a closed jar containing $5 \mathrm{ml}$ of $\mathrm{NaOH}(0.1 \mathrm{M})$ in a flask inside it, for 10 days at $25^{\circ} \mathrm{C}$. After incubation the $\mathrm{NaOH}$ was titrated with $1 \mathrm{~N} \mathrm{HCl}$ followed by the addition of $1 \mathrm{ml} \mathrm{BaCl}_{2}$ and two drops of phenolphthalein indicator in $\mathrm{NaOH}$. The basal respiration was computed using the difference of the $\mathrm{HCl}$ volume used for the titration of sample and the control. The final value was expressed as the amount of $\mathrm{CO}_{2}$ evolved from microbes present per gm of soil per hour $\left(\mu \mathrm{g} \mathrm{CO}_{2} \mathrm{~g}^{-1}\right.$ soil $\left.\mathrm{h}^{-1}\right)$. The metabolic quotient $\left(q \mathrm{CO}_{2}\right)$ was calculated as the ratio of basal respiration $\left(\mu \mathrm{g} \mathrm{CO}_{2} \mathrm{~g}^{-1}\right.$ soil h$\left.^{-1}\right)$ to $\mathrm{MBC}$.

\section{Soil enzymatic assay}

The activity of acid phosphatase (EC 3.1.3.2) and $\beta$-glucosidase (EC 3.2.1.21) were determined as described by Eivazi and Tabatabai $(1977,1988)$. P-Nitro phenyl phosphate and $p$-nitro phenyl- $\beta$-D-glucopyranoside ( $p$ NPG) was used as a substrate, respectively, and the quantity of p-nitrophenol released during the incubation of per gram sample with substrate at $37^{\circ} \mathrm{C}$ for $1 \mathrm{~h}$ was measured at $400 \mathrm{~nm}$.

The activity of protease (EC 3.4.21.19) was measured using tyrosine as standard and the amount of amino acids released after incubation of the sample with casein for $2 \mathrm{~h}$ at $50{ }^{\circ} \mathrm{C}$ was quantified by Ladd and Butler (1972) protocol and the final absorbance were measured at $700 \mathrm{~nm}$.

The dehydrogenase (EC 1.1.1) assay was done using Casida et al. (1964), measured the reduction of 2, 3, 5-triphenyltetrazolium chloride (TTC) to triphenyl formazan on incubation at $30{ }^{\circ} \mathrm{C}$ for $24 \mathrm{~h}$ and the absorbance were taken at $485 \mathrm{~nm}$.

Fluorescein diacetate (FDA) hydrolysis assay was determined by the method described by Stubberfield and Shaw (1990). In brief, 2-g soil sample was mixed with $15 \mathrm{ml}$ of phosphate buffer $(60 \mathrm{mM}, \mathrm{pH} 7.6)$ and FDA solution (prepare in acetone), incubated at $30{ }^{\circ} \mathrm{C}$, on an orbital shaker. The reaction was stopped after $20 \mathrm{~min}$ by adding chloroform:methanol solution $(2: 1)$. Then the soil suspension was centrifuged and absorbance of supernatant was taken at $490 \mathrm{~nm}$.

\section{Statistical analysis}

Data were summarized as mean \pm SD (standard deviation). Groups were compared by Student's $t$ test. The groups were also compared by one-way analysis of variance (ANOVA) and the significance of mean difference between the groups was done by Duncan multiple range test (DMRT) and Bonferroni test after adjusting the multiple contrasts. Pearson correlation analysis was done to assess associations between the variables. A two-tailed $(\alpha=2) P$ value less than $0.05(P<0.05)$ was considered statistically significant. Analyses were performed using SPSS software (version 16.0).

\section{Results}

\section{Soil physico-chemical characteristics}

The physical characteristics of soil of five subgroups (sal, sal-mixed, oak, pine and oak-mixed) and two groups (dry deciduous forest and temperate forest) are summarized in (Tables 2, 3). Among subgroups, the $\mathrm{pH}$ of the soils ranged from 6.33 to 6.88 . The $\mathrm{pH}$ was highest in oak and least at sal soil. The highest EC was recorded in oak soil (265.33). The soil of sal-mixed stand located in the dry deciduous region had the lowest EC value of 31.33. Comparing each physical and chemical characteristic among the subgroups, ANOVA/Bonferroni test revealed significant $(P<0.01$ or $P<0.001)$ different characteristics among the subgroups. The mean physico-chemical levels of most of the variables were highest at soil of oak-dominated stand.

Further, comparing the mean physical characteristic of each between the two groups, $t$ test revealed significant $(P<0.05$ or $P<0.01$ or $P<0.001)$ difference. Higher 
Table 2 Physical characteristics of selected stands

\begin{tabular}{|c|c|c|c|c|c|}
\hline \multirow[t]{2}{*}{ Soil parameters } & \multicolumn{2}{|l|}{ Dry deciduous forest } & \multicolumn{3}{|l|}{ Temperate forest } \\
\hline & Forest stand 1 & Forest stand 2 & Forest stand 3 & Forest stand 4 & Forest stand 5 \\
\hline Clay $(\%)$ & $27.33 \pm 1.15(\mathrm{c})$ & $19.33 \pm 1.15(\mathrm{~d})$ & $17.33 \pm 1.15(\mathrm{~d})$ & $39.33 \pm 1.15$ (a) & $34.67 \pm 1.15(\mathrm{~b})$ \\
\hline Slit $(\%)$ & $6.00 \pm 2.00(\mathrm{~d})$ & $20.67 \pm 1.15$ (a) & $9.33 \pm 1.15(\mathrm{c})$ & $8.00 \pm 2.00(\mathrm{~cd})$ & $16.67 \pm 1.15(b)$ \\
\hline Sand $(\%)$ & $66.67 \pm 1.15(b)$ & $60.00 \pm 0.00(\mathrm{c})$ & $73.33 \pm 1.15(\mathrm{a})$ & $52.67 \pm 1.15(\mathrm{~d})$ & $48.67 \pm 1.15(\mathrm{e})$ \\
\hline Bulk density $\left(\mathrm{g} \mathrm{cc}^{-1}\right)$ & $1.15 \pm 0.02(b)$ & $1.30 \pm 0.14$ (a) & $1.02 \pm 0.01(\mathrm{c})$ & $0.99 \pm 0.01(\mathrm{c})$ & $1.09 \pm 0.01(\mathrm{bc})$ \\
\hline Particle density & $1.72 \pm 0.08(b)$ & $2.94 \pm 0.56$ (a) & $1.43 \pm 0.22(\mathrm{~b})$ & $1.34 \pm 0.06(b)$ & $1.34 \pm 0.14(b)$ \\
\hline Porosity $(\%)$ & $32.89 \pm 4.27(b)$ & $54.07 \pm 14.42(\mathrm{a})$ & $27.72 \pm 9.95(b)$ & $25.79 \pm 2.81(\mathrm{~b})$ & $18.19 \pm 9.21(\mathrm{~b})$ \\
\hline WHC (\%) & $50.67 \pm 3.96(\mathrm{ab})$ & $45.87 \pm 1.87(b)$ & $53.86 \pm 5.27$ (a) & $48.89 \pm 2.33(\mathrm{ab})$ & $47.05 \pm 3.22(\mathrm{ab})$ \\
\hline Moisture (\%) & $16.99 \pm 0.93(\mathrm{ab})$ & $16.11 \pm 0.25(\mathrm{~b})$ & $18.32 \pm 1.05$ (a) & $17.72 \pm 0.91(\mathrm{a})$ & $16.09 \pm 0.63(\mathrm{~b})$ \\
\hline
\end{tabular}

Values are mean $\pm \mathrm{SD}$ and letters represent difference significant at $P<0.05$

WHC water holding capacity

Table 3 Chemical characteristics of selected stands

\begin{tabular}{|c|c|c|c|c|c|}
\hline \multirow[t]{2}{*}{ Soil parameters } & \multicolumn{2}{|l|}{ Dry deciduous forest } & \multicolumn{3}{|l|}{ Temperate forest } \\
\hline & Forest stand 1 & Forest stand 2 & Forest stand 3 & Forest stand 4 & Forest stand 5 \\
\hline $\mathrm{pH}$ & $6.36 \pm 0.04(\mathrm{~d})$ & $6.33 \pm 0.01(\mathrm{c})$ & $6.48 \pm 0.02(b)$ & $6.61 \pm 0.05(b)$ & $6.88 \pm 0.02$ (a) \\
\hline $\mathrm{EC}$ & $83.67 \pm 0.91(\mathrm{~d})$ & $31.33 \pm 1.09(\mathrm{e})$ & $109.63 \pm 1.06(\mathrm{c})$ & $190.73 \pm 10.36(b)$ & $265.33 \pm 7.74$ (a) \\
\hline TOC $\left(\mathrm{mg} \mathrm{g}^{-1}\right)$ & $3.71 \pm 0.92(\mathrm{e})$ & $9.02 \pm 0.92(d)$ & $45.11 \pm 2.30$ (a) & $41.79 \pm 1.99(b)$ & $28.39 \pm 0.46(\mathrm{c})$ \\
\hline $\mathrm{TP}\left(\mathrm{mg} \mathrm{g}^{-1}\right)$ & $0.26 \pm 0.01(\mathrm{e})$ & $0.29 \pm 0.01(\mathrm{~d})$ & $0.32 \pm 0.01(\mathrm{c})$ & $0.37 \pm 0.01(b)$ & $0.56 \pm 0.02$ (a) \\
\hline $\mathrm{TN}\left(\mathrm{mg} \mathrm{g}^{-1}\right)$ & $0.64 \pm 0.03(\mathrm{e})$ & $0.75 \pm 0.01(\mathrm{~d})$ & $2.14 \pm 0.06(\mathrm{c})$ & $3.16 \pm 0.02(a)$ & $2.27 \pm 0.06(b)$ \\
\hline $\mathrm{TK}\left(\mathrm{mg} \mathrm{g}^{-1}\right)$ & $23.26 \pm 0.42(b)$ & $26.67 \pm 0.18$ (a) & $7.44 \pm 0.42(\mathrm{~d})$ & $3.64 \pm 0.05(\mathrm{e})$ & $16.04 \pm 1.14(\mathrm{c})$ \\
\hline $\mathrm{AN}\left(\mu \mathrm{g} \mathrm{g}^{-1}\right)$ & $299.52 \pm 64.85(\mathrm{c})$ & $224.64 \pm 85.79$ (c) & $767.52 \pm 56.16(b)$ & $1216.80 \pm 112.32$ (a) & $748.80 \pm 85.79(b)$ \\
\hline $\mathrm{NH}_{3}-\mathrm{N}\left(\mu \mathrm{g} \mathrm{g}^{-1}\right)$ & $3.50 \pm 0.25(\mathrm{~d})$ & $4.87 \pm 0.24(\mathrm{~d})$ & $2.85 \pm 0.63(\mathrm{c})$ & $6.54 \pm 0.09$ (a) & $6.62 \pm 0.08(b)$ \\
\hline $\mathrm{NO}_{3}-\mathrm{N}\left(\mu \mathrm{g} \mathrm{g}^{-1}\right)$ & $2.05 \pm 0.81(\mathrm{~d})$ & $1.01 \pm 0.47(\mathrm{c})$ & $1.23 \pm 0.78(\mathrm{e})$ & $6.15 \pm 0.34(b)$ & $6.22 \pm 0.56(\mathrm{a})$ \\
\hline $\mathrm{AP}\left(\mu \mathrm{g} \mathrm{g}^{-1}\right)$ & $39.87 \pm 1.87(\mathrm{c})$ & $42.18 \pm 2.55(\mathrm{c})$ & $37.71 \pm 3.88(\mathrm{c})$ & $134.51 \pm 24.28(\mathrm{~b})$ & $201.71 \pm 9.73$ (a) \\
\hline $\mathrm{ANa}\left(\mu \mathrm{g} \mathrm{g}^{-1}\right)$ & $58.05 \pm 0.99(\mathrm{~b})$ & $28.24 \pm 1.97(\mathrm{~d})$ & $27.47 \pm 1.04(\mathrm{~d})$ & $38.19 \pm 1.72(\mathrm{c})$ & $164.72 \pm 3.60(\mathrm{a})$ \\
\hline $\mathrm{AK}\left(\mu \mathrm{g} \mathrm{g}^{-1}\right)$ & $24.37 \pm 2.00(\mathrm{e})$ & $55.76 \pm 6.17(\mathrm{~d})$ & $143.28 \pm 1.87(\mathrm{c})$ & $489.09 \pm 3.42$ (a) & $255.79 \pm 4.06(\mathrm{~b})$ \\
\hline $\mathrm{ACa}\left(\mu \mathrm{g} \mathrm{g}^{-1}\right)$ & $80.72 \pm 3.68(\mathrm{e})$ & $385.52 \pm 3.69(\mathrm{~d})$ & $753.07 \pm 1.12(\mathrm{c})$ & $784.53 \pm 5.31(b)$ & $968.03 \pm 6.43(\mathrm{a})$ \\
\hline $\mathrm{C} / \mathrm{N}\left(\mu \mathrm{g} \mathrm{g}^{-1}\right)$ & $5.81 \pm 1.24(\mathrm{c})$ & $11.98 \pm 1.29(\mathrm{~b})$ & $21.07 \pm 1.66(\mathrm{a})$ & $13.21 \pm 0.61(b)$ & $12.49 \pm 0.38(\mathrm{~b})$ \\
\hline
\end{tabular}

Values are mean $\pm \mathrm{SD}$ and letters represent difference significant at $P<0.05$

$T O C$ total organic carbon, $T P$ total phosphorous, $T N$ total nitrogen, $T K$ total potassium, $A N$ available nitrogen, $A P$ available phosphorous, $A N a$ available sodium, $A K$ available potassium, $A C a$ available calcium

bulk density, particle density and porosity are found in dry deciduous forest as compared to temperate forest while $\mathrm{pH}$ and EC were significantly $(P<0.01)$ different and higher in temperate forest as compared to dry deciduous forest. However, some of the characteristics did not differ $(P>0.01)$ between the two groups and were found to be statistically the same.

\section{Soil microbial biomass $\mathbf{C}, \mathbf{N}$ and $\mathbf{P}$}

The microbial biomass characteristics of soil of five subgroups and two groups are summarized in (Fig. 2 and Table 4). Soil microbial biomass carbon (MBC) ranged from 140.75 to $313 \mu \mathrm{g} \mathrm{g}^{-1}$. Both the oak-mixed and oak soil had the highest MBC whereas the soil of sal stand had the lowest MBC, i.e., $140 \mu \mathrm{g} \mathrm{g}^{-1}$. The MBC in the case of oak soil was found to be just double of that of the value obtained from the sal soil. In case of MBN, oak soil had the highest MBN and sal soil had the lowest MBN value. The value of MBN varied from 35.55 to $71.35 \mu \mathrm{g} \mathrm{g}^{-1}$. The MBP value was higher in soil of oak-dominated stand, i.e. $46.66 \mu \mathrm{g} \mathrm{g}^{-1}$ and lowest in the soil of sal stand. Statistical analysis revealed significant variations among the soil microbial characteristics. Comparing the mean microbial biomass level of the subgroups, ANOVA/Bonferroni test revealed significantly $(P<0.05$ or $P<0.01$ or $P<0.001)$ 
Fig. 2 Microbial biomass a carbon, b nitrogen, c phosphorous of soil samples collected from selected stands. Values are expressed as mean \pm SD and letters represent difference significant at $P<0.05$
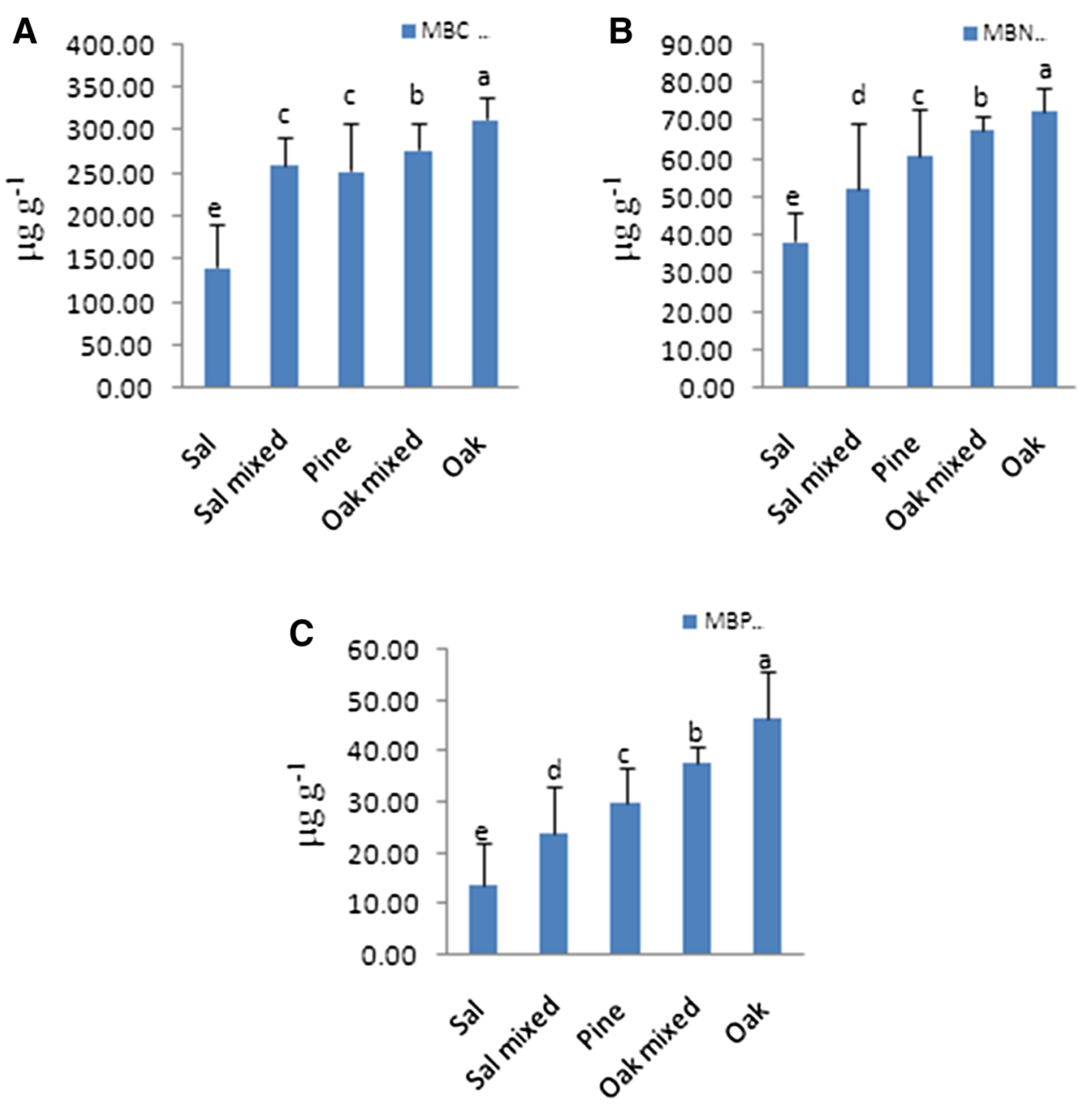

Table 4 Microbial biomass $\mathrm{C}, \mathrm{N}$ and $\mathrm{P}$ ratio of selected stands

\begin{tabular}{|c|c|c|c|c|c|}
\hline \multirow[t]{2}{*}{$\mathrm{C}: \mathrm{N}: \mathrm{P}$ ratio } & \multicolumn{2}{|c|}{ Dry deciduous forest } & \multicolumn{3}{|c|}{ Temperate forest } \\
\hline & Forest stand 1 & Forest stand 2 & Forest stand 3 & Forest stand 4 & Forest stand 5 \\
\hline $\mathrm{BR} / \mathrm{MBC}\left(q \mathrm{CO}_{2}\right)$ & 0.14 & 0.14 & 0.10 & 0.17 & 0.18 \\
\hline $\mathrm{MBC} / \mathrm{TOC}$ & 3.92 & 1.44 & 0.46 & 0.32 & 0.36 \\
\hline $\mathrm{MBC} / \mathrm{MBN}$ & 3.89 & 5.31 & 4.14 & 4.08 & 4.37 \\
\hline MBN/TN (\%) & 6.03 & 6.95 & 2.86 & 2.15 & 3.19 \\
\hline MBP/TP (\%) & 5.36 & 8.39 & 9.26 & 10.11 & 8.36 \\
\hline MBC/MBP & 12.97 & 12.61 & 8.58 & 7.43 & 6.89 \\
\hline
\end{tabular}

different levels and the mean microbial biomass levels were highest at soil of oak-dominated stand while least at sal-dominated soil. Similarly, there is significant effect of forest type on soil $\mathrm{MBC} / \mathrm{TOC}$, i.e., microbial quotient, $\mathrm{MBN} / \mathrm{TN}$ and MBN/TP ratios.

The comparison of mean microbial biomass level of each between the two groups, $t$ test revealed significant $(P<0.05$ or $P<0.01$ or $P<0.001)$ difference among the two forest type. The overall MBC, MBN, and MBP were recorded higher in temperate as compared to dry deciduous forest.

\section{Soil basal respiration and metabolic quotient $\left(\mathrm{qCO}_{2}\right)$}

The basal respiration is high in the soil of oak-mixed stand that was recorded highest among all the forest (Fig. 3); it declined to 16.01 in the sal soil. The variation in the pattern of respiration values is quite low and it ranged from $20.53 \mu \mathrm{g} \mathrm{CO}_{2} \mathrm{~g}^{-1}$ soil $\mathrm{h}^{-1}$ in oak-mixed stand, followed by $18.82 \mu \mathrm{g} \mathrm{CO}_{2} \mathrm{~g}^{-1}$ soil h$^{-1}$ in pine-dominated stand, $17.84 \mu \mathrm{g} \mathrm{CO}_{2} \mathrm{~g}^{-1}$ soil $\mathrm{h}^{-1}$ in oak-dominated soil which is similar to sal soil and lowest in the soil of sal-mixed stand, 


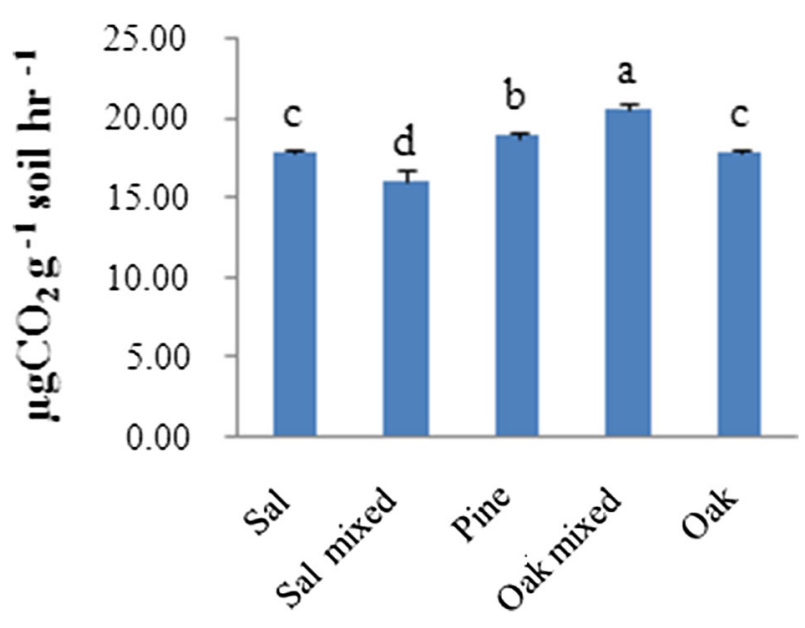

Fig. 3 Basal respiration (Bs) in soil collected from selected stands. Values are mean $\pm \mathrm{SD}$ and letters represent difference significant at $P<0.05$ whereas the value of metabolic quotient $\left(q \mathrm{CO}_{2}\right)$ varied from 0.10 to 0.18 . The $q \mathrm{CO}_{2}$ was high in soil of oakdominated stand located in temperate region.

Comparing the mean level of soil basal respiration and metabolic quotient $\left(q \mathrm{CO}_{2}\right)$ of each among the subgroups, ANOVA/Bonferroni test revealed different levels of significance $(P<0.05$ or $P<0.01$ or $P<0.001)$.

Further, comparing the mean respiration level of each between the two groups, $\mathrm{t}$ test revealed significant $(P<0.05$ or $P<0.01$ or $P<0.001)$ difference among the two forest types and higher respiration rate and metabolic quotient in temperate forest as compared to dry deciduous forest type.

\section{Enzyme activities}

The enzyme activities of soil of five subgroups are summarized in Fig. 4. The enzymatic activity of selected soil
Fig. 4 Enzyme activities of soil samples collected from selected stands. a Acid phosphatase, $\mathbf{b} \beta$ glucosidase, $\mathbf{c}$ dehydrogenase, d protease, $\mathbf{e}$ fluorescein diacetate. Values are mean $\pm \mathrm{SD}$ and letters represent difference significant at $P<0.05$

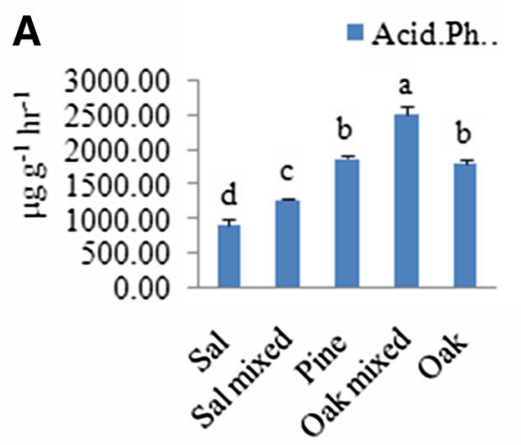

B
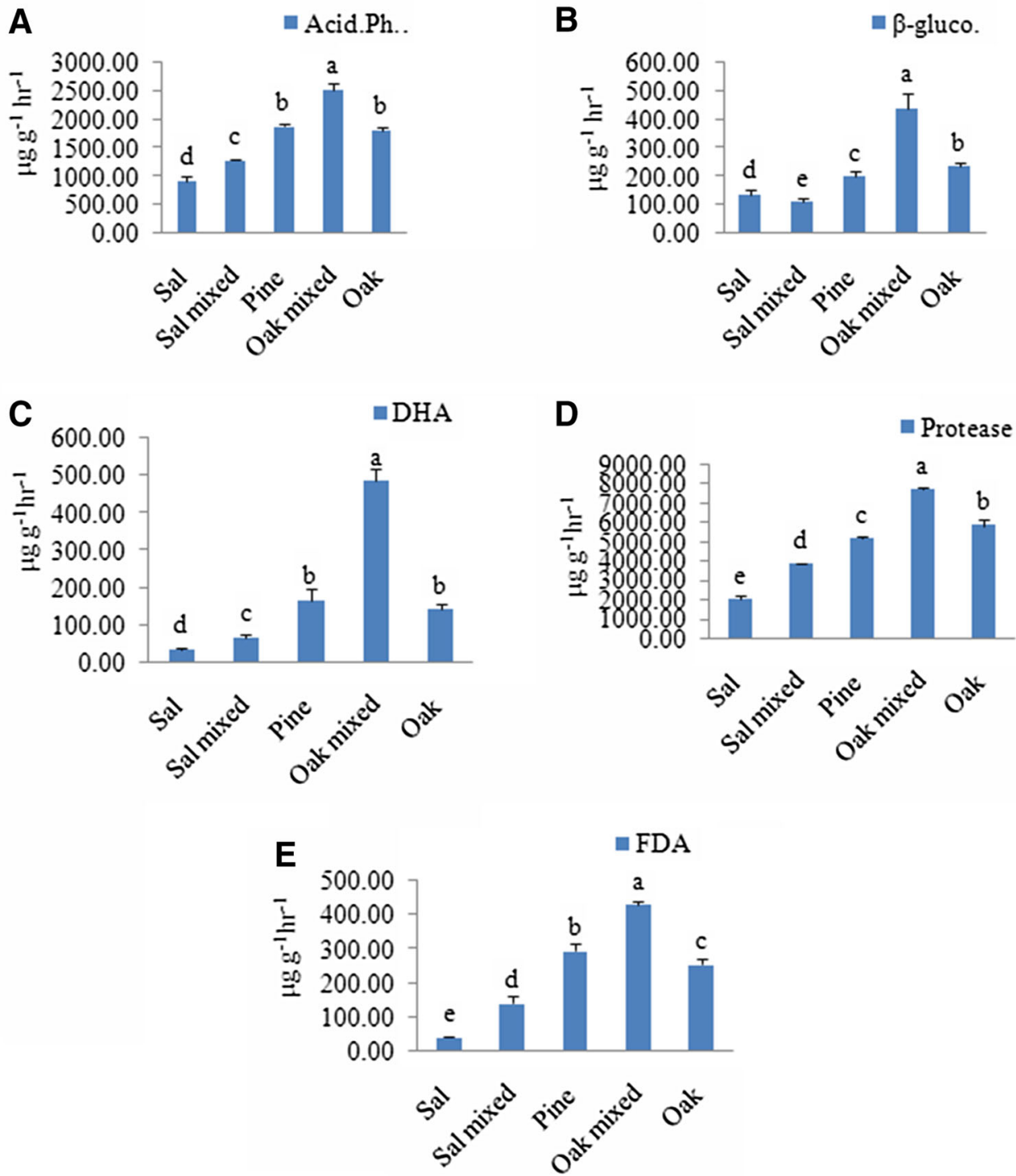
samples were also varied with forest types, which ranging from 929 to $2525.01 \mu \mathrm{g} \mathrm{g}^{-1} \mathrm{~h}^{-1}$ for acid phosphates, 110.73 to $441.50 \mu \mathrm{g} \mathrm{g}^{-1} \mathrm{~h}^{-1}$ for $\beta$-glucosidase, and DHA varied from 35 to $485.35 \mu \mathrm{g} \mathrm{g}^{-1} \mathrm{~h}^{-1}$. The value of protease varied from 2018.60 to $7721.07 \mu \mathrm{g} \mathrm{g}^{-1} \mathrm{~h}^{-1}$ and for FDA it ranged from 41.06 to $429.42 \mu \mathrm{g} \mathrm{g}^{-1} \mathrm{~h}^{-1}$. Among subgroups, the mean enzyme activities were recorded highest in soil of oak-mixed stand and least mostly at sal soil, and ANOVA/Bonferroni test revealed significantly $(P<0.001)$ different enzyme activities among the subgroups.

Further, ttest revealed significant $(P<0.01$ or $P<0.001)$ difference in the enzyme activity of each between the two groups and higher acid phosphatase, $\beta$ glucosidase, DHA, protease and FDA activity in temperate forest as compared to dry deciduous forest.

\section{Pearson's correlation analysis}

Pearson's correlation revealed that different soil variables were significantly correlated with each other. A diverse range of correlation was recorded among different variable. The $\mathrm{pH}$ was positively correlated with biological parameters including TOC, MBC, MBN, MBP, basal respiration and enzymatic activity. Additionally, basal respiration, MBC, MBN, MBP, TOC and activities of DHA and FDA were positively correlated with each other. Similarly, activities of acid phosphates, $\beta$-glucosidase and protease were significantly correlated with AP, TP, AN, TN, TOC, $\mathrm{NH}_{4}{ }^{+}-\mathrm{N}, \mathrm{NO}_{3}{ }^{-}-\mathrm{N}, \mathrm{ACa}$ with an exception of TK which was negatively correlated with most of the biological variables and enzymatic activity (Table 5).

\section{Discussion}

The $\mathrm{pH}$ of all the soil samples was acidic in nature. The availability of nutrients for plant is highly influenced by soil pH and it indicates the soil fertility (Zhao et al. 2012). The presence of dense fine root on the top layer of soil and higher organic carbon content results in high WHC among the oak-mixed soil and the values were comparable with other results (Paudel and Sah 2003).

Soil microbial biomass indicates the living portion of soil organic matter and is mainly responsible for the conversion of complex into available form of nutrients. The soil microbial status is emphasized by the microbial biomass and activity (Altieri 1999). In the study, the soil with microbial biomass, i.e., $\mathrm{MBC}, \mathrm{MBN}$ and $\mathrm{MBP}$ was extensively found in temperate region indicating the higher availability of nutrients in the respective region and the values were in the range same as recorded by Tripathi and Singh 2013. MBC was observed as positively correlated with soil total organic carbon (TOC) in the study, which is congruent with the findings of Yang et al. 2010; Wang and Wang 2007. TOC, MBC and the enzymatic activity were comparatively low in Sal stand than other stand. The soil organic matter governs its physico-chemical characteristics and provides favorable conditions for the survival of functional groups (Horwath 2005). The lowering in the soil organic matter in sal stand directly depleted the concentration of essential nutrients. Additionally, variation in accessibility of nutrients is explicated by the pattern of forest succession that is responsible for the difference in organic matter content. This eventual difference creates a significant variation in the pattern of total carbon, nitrogen and phosphorous content among the selected stands in the study.

It is observed that microbial $\mathrm{C} / \mathrm{N}$ is low in temperate region, which is in contrast with the study of Carter (1986). Under different conditions, the comparison between the variations in microbial $\mathrm{C} / \mathrm{N}$ is not always possible as the mineralization rate may vary with changes in conditions (Brookes et al. 1984; Dalal and Mayer 1987). The high $\mathrm{MBC} / \mathrm{TOC}$ ratio in dry deciduous forest is evidence of the contribution of MBC to TOC that may be the result of high diversity in organic substrate production from the mixed species present. This ratio is also helpful in evaluation of the soil labile carbon availability as well as fraction of soil recalcitrant organic matter and is also used as an indicator of changes in organic matter due to alterations of soil conditions in future (Cheng et al. 2013). The MBC/TOC ratio or microbial quotient in soil has been used for comparing the soil quality parameter across soils with different organic matter content.

The lower values of $\mathrm{MBC} / \mathrm{TOC}$ in temperate region indicate the lower accessibility of organic substrates provided by the litter of this region. Similarly MBN/TN and $\mathrm{MBP} / \mathrm{TP}$ represent the availability of nitrogen and phosphorous. In this study, the highest $\mathrm{MBN} / \mathrm{TN}$ ratio in dry deciduous forest, dominated by sal plantation represents high mineralization and availability of nitrogen in this region whereas nitrogen availability was found to be low in temperate region (Chen et al. 2005). In addition, the Pearson's correlation suggests positive correlation between $\mathrm{pH}$ and microbial biomass, which supports the microbial growth and activity (Aciego and Brookes 2009). Soil micro flora contains several microorganisms that belong to different groups. $\mathrm{C} / \mathrm{N}$ ratio for each microbial group is different which ranges from 3 to 5 for bacteria, while for fungi, it ranges from 4 to 15 (Recous and Mary 1990). The $\mathrm{MBC} / \mathrm{MBN}$ ratio in dry deciduous forest reflects the dominance of bacteria in soil microbial biomass whereas in case of temperate region this ratio indicates the abundance of fungal communities in soil microbial biomass. Moreover, maintenance requirements for microbial cells are high under acidic condition of forest soil. Consequently, 
Table 5 Pearson's correlation coefficient $(r)$ between soil physico-chemical and microbial properties

\begin{tabular}{|c|c|c|c|c|c|c|c|c|c|}
\hline & Clay & Slit & Sand & $\mathrm{pH}$ & EC & BD & PD & Porosity & WHC \\
\hline Slit & -0.249 & 1 & & & & & & & \\
\hline Sand & $-0.789 * *$ & -0.398 & 1 & & & & & & \\
\hline $\mathrm{pH}$ & 0.385 & 0.146 & -0.458 & 1 & & & & & \\
\hline $\mathrm{EC}$ & 0.105 & $0.889 * *$ & $-0.663 * *$ & 0.281 & 1 & & & & \\
\hline $\mathrm{BD}$ & -0.412 & $0.563^{*}$ & 0.033 & $-0.565^{*}$ & 0.469 & 1 & & & \\
\hline PD & -0.507 & $0.591^{*}$ & 0.106 & $-0.527^{*}$ & 0.502 & $0.669 * *$ & 1 & & \\
\hline Porosity & -0.492 & 0.373 & 0.230 & $-0.554^{*}$ & 0.307 & 0.496 & $0.944 * *$ & 1 & \\
\hline WHC & -0.243 & $-0.577^{*}$ & $0.596^{*}$ & 0.000 & $-0.622 *$ & -0.391 & -0.418 & -0.345 & 1 \\
\hline TOC & 0.213 & -0.243 & -0.048 & $0.849 * *$ & -0.144 & $-0.778 * *$ & $-0.593 *$ & -0.484 & 0.288 \\
\hline MBC & 0.263 & 0.465 & $-0.544^{*}$ & $0.759 * *$ & $0.582 *$ & -0.227 & -0.081 & -0.192 & -0.307 \\
\hline MBP & 0.513 & 0.205 & $-0.616^{*}$ & $0.819 * *$ & 0.402 & -0.339 & -0.433 & -0.440 & -0.208 \\
\hline MBN & 0.225 & 0.260 & -0.378 & $0.691 * *$ & 0.384 & -0.350 & -0.148 & -0.247 & 0.040 \\
\hline AN & $0.628^{*}$ & -0.371 & -0.359 & $0.772 * *$ & -0.100 & $-0.798 * *$ & $-0.679 * *$ & $-0.565^{*}$ & 0.182 \\
\hline $\mathrm{TN}$ & $0.599 *$ & -0.225 & -0.425 & $0.879 * *$ & 0.008 & $-0.772 * *$ & $-0.667 * *$ & $-0.602 *$ & 0.114 \\
\hline NH3 & $0.642 * *$ & -0.086 & $-0.553^{*}$ & $0.900 * *$ & 0.146 & $-0.696 * *$ & $-0.612 *$ & $-0.575^{*}$ & -0.030 \\
\hline NO3 & $0.907 * *$ & 0.005 & $-0.862 * *$ & $0.654 * *$ & 0.264 & -0.447 & $-0.565^{*}$ & $-0.610^{*}$ & -0.277 \\
\hline AP & $0.795 * *$ & 0.182 & $-0.869 * *$ & $0.705 * *$ & 0.415 & -0.346 & -0.466 & $-0.550 *$ & -0.304 \\
\hline $\mathrm{TP}$ & $0.563^{*}$ & 0.314 & $-0.732 * *$ & $0.778 * *$ & 0.424 & -0.336 & -0.450 & $-0.571 *$ & -0.222 \\
\hline $\mathrm{ANa}$ & 0.487 & 0.265 & $-0.630^{*}$ & 0.402 & 0.295 & -0.086 & -0.366 & -0.512 & -0.250 \\
\hline $\mathrm{AK}$ & $0.780 * *$ & -0.194 & $-0.615^{*}$ & $0.730 * *$ & 0.134 & $-0.636^{*}$ & $-0.533^{*}$ & -0.478 & -0.075 \\
\hline TK & -0.387 & 0.476 & 0.064 & $-0.730 * *$ & 0.318 & $0.851 * *$ & $0.711 * *$ & $0.573 *$ & -0.346 \\
\hline $\mathrm{ACa}$ & 0.375 & 0.200 & -0.482 & $0.994 * *$ & 0.317 & $-0.552 *$ & -0.498 & $-0.533^{*}$ & -0.028 \\
\hline BR & $0.559^{*}$ & $-0.675 * *$ & -0.101 & 0.478 & -0.465 & $-0.853 * *$ & $-0.734 * *$ & $-0.547 *$ & 0.381 \\
\hline Acidpho & $0.519^{*}$ & -0.145 & -0.400 & $0.850 * *$ & 0.111 & $-0.687 * *$ & -0.508 & -0.439 & 0.087 \\
\hline Bgluco & $0.748 * *$ & -0.346 & -0.489 & $0.618^{*}$ & -0.037 & $-0.684 * *$ & $-0.572 *$ & -0.482 & 0.026 \\
\hline DHA & $0.648 * *$ & -0.323 & -0.409 & $0.594 *$ & 0.002 & $-0.631^{*}$ & -0.441 & -0.327 & 0.002 \\
\hline Protease & $0.561^{*}$ & 0.016 & $-0.541^{*}$ & $0.881 * *$ & 0.265 & $-0.604^{*}$ & -0.454 & -0.440 & -0.053 \\
\hline \multirow[t]{2}{*}{ FDA } & 0.458 & -0.127 & -0.353 & $0.847 * *$ & 0.099 & $-0.699 * *$ & -0.484 & -0.423 & 0.104 \\
\hline & TOC & MBC & MBP & AN & $\mathrm{TN}$ & $\mathrm{NH}_{3}$ & $\mathrm{NO}_{3}$ & $\mathrm{AP}$ & TP \\
\hline
\end{tabular}

Slit

Sand

$\mathrm{pH}$

EC

BD

PD

Porosity

WHC

TOC 1

MBC $0.517^{*} \quad 1$

$\begin{array}{llll}\text { MBP } & 0.584 * & 0.726 * * & 1\end{array}$

$\begin{array}{llllll}\text { AN } & 0.859 * & 0.448 & 0.641 * & 0.456 & 1\end{array}$

$\begin{array}{lllllll}\text { TN } & 0.898 * * & 0.579 * & 0.695 * * & 0.523 * & 0.967 * * & 1\end{array}$

\begin{tabular}{llllllllll} 
NH3 & $0.834 * *$ & $0.653^{* *}$ & $0.773^{* *}$ & $0.516^{*}$ & $0.926^{* *}$ & $0.974^{* *}$ & 1 & & \\
NO3 & 0.379 & 0.483 & $0.698^{* *}$ & 0.424 & $0.660^{* *}$ & $0.713^{* *}$ & $0.778^{* *}$ & 1 & \\
AP & 0.335 & $0.576^{*}$ & $0.769^{* *}$ & $0.548^{*}$ & $0.563^{*}$ & $0.629^{*}$ & $0.732^{* *}$ & $0.943^{* *}$ & 1 \\
TP & 0.391 & $0.677^{* *}$ & $0.805^{* *}$ & $0.613^{*}$ & 0.465 & $0.576^{*}$ & $0.678^{* *}$ & $0.818^{* *}$ & $0.931^{* *}$ \\
\hline
\end{tabular}


Table 5 continued

\begin{tabular}{|c|c|c|c|c|c|c|c|c|c|c|}
\hline & TOC & MBC & MBP & $\mathrm{MBN}$ & AN & $\mathrm{TN}$ & $\mathrm{NH}_{3}$ & $\mathrm{NO}_{3}$ & $\mathrm{AP}$ & $\mathrm{TP}$ \\
\hline $\mathrm{ANa}$ & -0.029 & 0.338 & $0.534 *$ & 0.378 & 0.086 & 0.177 & 0.281 & $0.681 * *$ & $0.806^{* *}$ & $0.867 * *$ \\
\hline $\mathrm{AK}$ & $0.705^{* *}$ & $0.521^{*}$ & $0.636^{*}$ & 0.432 & $0.924 * *$ & $0.932 * *$ & $0.928 * *$ & $0.798 * *$ & $0.670 * *$ & 0.510 \\
\hline TK & $-0.944 * *$ & -0.359 & -0.477 & -0.356 & $-0.927 * *$ & $-0.924 * *$ & $-0.844 * *$ & -0.447 & -0.325 & -0.294 \\
\hline $\mathrm{ACa}$ & $0.818 * *$ & $0.783 * *$ & $0.838 * *$ & $0.695 * *$ & $0.740 * *$ & $0.849 * *$ & $0.882 * *$ & $0.660 * *$ & $0.728 * *$ & $0.815 * *$ \\
\hline $\mathrm{BR}$ & $0.730 * *$ & 0.069 & 0.324 & 0.162 & $0.893 * *$ & $0.812 * *$ & $0.732 * *$ & 0.494 & 0.316 & 0.169 \\
\hline Acidpho & $0.891 * *$ & $0.582^{*}$ & $0.652 * *$ & $0.553 *$ & $0.943 * *$ & $0.971 * *$ & $0.937 * *$ & $0.618 *$ & $0.534 *$ & 0.470 \\
\hline Bgluco & $0.687 * *$ & 0.365 & $0.517 *$ & 0.339 & $0.918 * *$ & $0.895 * *$ & $0.851 * *$ & $0.719 * *$ & $0.534 *$ & 0.365 \\
\hline DHA & $0.713 * *$ & 0.404 & 0.469 & 0.302 & $0.903 * *$ & $0.874 * *$ & $0.839 * *$ & $0.592 *$ & 0.430 & 0.242 \\
\hline Protease & $0.830 * *$ & $0.701 * *$ & $0.705^{* *}$ & $0.582 *$ & $0.898 * *$ & $0.955 * *$ & $0.956 * *$ & $0.697 * *$ & $0.634 *$ & $0.575^{*}$ \\
\hline \multirow[t]{2}{*}{ FDA } & $0.906^{* *}$ & $0.608^{*}$ & $0.610^{*}$ & $0.558^{*}$ & $0.927 * *$ & $0.963 * *$ & $0.927 * *$ & $0.568 *$ & 0.487 & 0.442 \\
\hline & ANa & AK & TK & \multicolumn{2}{|c|}{$\mathrm{ACa}$} & & Acidpho & Bgluco & DHA & Protease \\
\hline
\end{tabular}

Slit

Sand

$\mathrm{pH}$

EC

BD

PD

Porosity

WHC

TOC

$\mathrm{MBC}$

MBP

MBN

AN

TN

$\mathrm{NH} 3$

$\mathrm{NO} 3$

AP

TP

ANa $\quad 1$

$\begin{array}{lll}\text { AK } & 0.147 & 1\end{array}$

TK $\quad 0.091 \quad-0.795 * * \quad 1$

$\begin{array}{llll}\mathrm{ACa} & 0.453 & 0.698 * * & -0.683 * *\end{array}$

$\begin{array}{lllll}\mathrm{BR} & -0.100 & 0.781 * * & -0.897 * * & 0.435\end{array}$

$\begin{array}{lllllll}\text { Acidpho } & 0.023 & 0.929 * * & -0.897 * * & 0.814 * * & 0.765^{* *} & 1\end{array}$

$\begin{array}{llllllll}\text { Bgluco } & 0.034 & 0.966 * * & -0.817 * * & 0.580 * & 0.846 * * & 0.889 * * & 1\end{array}$

$\begin{array}{lrllllllll}\text { DHA } & -0.149 & 0.949 * * & -0.830^{* *} & 0.545^{*} & 0.832 * * & 0.911^{* *} & 0.941 * * & 1 \\ \text { Protease } & 0.133 & 0.936 * * & -0.817 * * & 0.858^{* *} & 0.668^{* *} & 0.976^{* *} & 0.867 * * & 0.879 * * & 1\end{array}$

$\begin{array}{lllllllll}\text { FDA }-0.021 & 0.905 * * & -0.904 * * & 0.813 * * & 0.750 * * & 0.992 * * & 0.870^{* *} & 0.896 * * & 0.974 * *\end{array}$

* Correlation is significant at the 0.05 level (2-tailed)

** Correlation is significant at the 0.01 level (2-tailed)

production of biomass is reduced that results in low $\mathrm{MBC} /$ TOC and MBN/TN ratio.

Estimation of basal respiration highlights the active portion of microbial biomass in soil. The result of this study indicates that the activity of microbes is high in oakmixed soil located in temperate region, sequentially measures the more decomposition of organic matter in this region. Metabolic quotient expresses the $\mathrm{CO}_{2}$ generated by microbial biomass and depends on the stress conditions by different factors (Anderson and Domsch 1990). The lower value of $q \mathrm{CO}_{2}$ in sal-mixed soil suggests less stress conditions to microorganisms indicating easier carbon 
utilization with low energy requirement and responsible for stable system in this region (Nsabimana et al. 2004).

Highest enzymatic activities in oak-mixed soil are the measure of high metabolic rate of viable soil microorganisms, which is considered as the reflection of high microbial activity and nutrient availability in this region. The enzymatic activity such as dehydrogenase together with basal respiration, $q \mathrm{CO}_{2}$ and $\mathrm{MBC}$ are the major parameters to influence the metabolic ability and functional quality of soil. In the study, the positive relationship between microbial biomass, soil organic matter and enzyme activities was observed which indicates that the enzymatic activities could be partly endocellular (Arunachalam and Pandey 2003).

From the study, it may conclude that the biochemical as well as microbial properties of soil is significantly affected by forest type. Shifting in tree species will manifest the forest and will also affect the physiochemical as well as the biological properties of soil. Due to the climate change and complexity in soil dynamics, it is difficult to measure the relationship between different soil characters and microbial activates accurately. Although, the present study provides a baseline conclusion about the influence of specific forest type on soil physico-chemical and biological condition.

Acknowledgments Authors are grateful to the Director, CSIR-NBRI for providing institutional support. UGC is gratefully acknowledged for the financial support during this research acknowledged. DST (Grant No. DST/CCP/PR/03/2011) supported by CSIR-Network Project BSC-0109 (SIMPLE) and this project.

\section{Compliance with ethical standards}

Conflict of interest The authors declare that there is no conflict of interests regarding the publication of this paper.

Open Access This article is distributed under the terms of the Creative Commons Attribution 4.0 International License (http:// creativecommons.org/licenses/by/4.0/), which permits unrestricted use, distribution, and reproduction in any medium, provided you give appropriate credit to the original author(s) and the source, provide a link to the Creative Commons license, and indicate if changes were made.

\section{References}

Aciego JP, Brookes P (2009) Substrate inputs and pH as factors controlling microbial biomass, activity and community structure in an arable soil. Soil Biol Biochem 41:1396-1405. doi:10.1016/ j.soilbio.2009.03.017

Altieri MA (1999) The ecological role of biodiversity in agroecosystems. Agric Ecosyst Environ 74:19-31. doi:10.1016/S01678809(99)00028-6

American Public Health Association APHA (1985) Standard methods for the examination of water and waste water, 19th edn. APHA, Washington DC

Anderson TH, Domsch KH (1990) Application of eco-physiological quotients $(q \mathrm{CO} 2$ and $q \mathrm{D})$ on microbial biomass from soils of different cropping history. Soil Biol Biochem 22:251-255. doi:10.1016/0038-0717(90)90094-G

Arunachalam A, Pandey HN (2003) Ecosystem restoration of Jhum fallows in northeast India: microbial $\mathrm{C}$ and $\mathrm{N}$ along altitudinal and successional gradients. Restor Ecol 11:168-173. doi:10. 1046/j.1526-100X.2003.00013.x

Black CA, Evans DD, Ensminger LE, White JL, Clark FE (1965) Methods of soil analysis. Monogr 9. American Society of Agronomy, ASA, Madison

Brookes PC, Powlson DS, Jenkinson DS (1982) Measurement of microbial biomass phosphorus in soil. Soil Biol Biochem 14:319-329. doi:10.1016/0038-0717(82)90001-3

Brookes PC, Powlson DS, Jenkinson DS (1984) Phosphorus in the soil microbial biomass. Soil Biol Biochem 16:169-175

Brookes PC, Landman A, Pruden G, Jenkinson DS (1985) Chloroform fumigation and release of soil $\mathrm{N}$ : a rapid direct extraction method to measure microbial biomass $\mathrm{N}$ in soil. Soil Biol Biochem 17:837-842. doi:10.1016/0038-0717(85)90144-0

Burton J, Chen CR, Xu ZH (2007) Gross nitrogen transformations in adjacent native and plantation forests of subtropical Australia. Soil Biol Biochem 39:426-433. doi:10.1016/j.soilbio.2006.08. 011

Carter MR (1986) Microbial biomass as an index for tillage induced changes in soil biological properties. Soil Tillage Res 7:29-40. doi:10.1016/0167-1987(86)90005-X

Casida LE, Klein DA, Santoro T (1964) Soil dehydrogenase activity. Soil Sci 98:371-376

Chen TH, Chiu CY, Tian GL (2005) Seasonal dynamics of soil microbial biomass in coastal sand dune forest. Pedobiologia 49:645-653. doi:10.1016/j.pedobi.2005.06.005

Cheng F, Peng X, Zhao P, Yuan J, Zhong C, Cheng Y, Cui C, Zhang S (2013) Soil microbial biomass, basal respiration and enzyme activity of main forest types in the Qinling mountains. PLos One 8:e67353. doi:10.1371/journal.pone.0067353

Dalal RC, Mayer RJ (1987) Long-term trends in fertility of soils under continuous cultivation and cereal cropping in Southern Queensland. VII. Dynamics of nitrogen mineralization potentials and microbial biomass. Aust J Soil Res 25:461-472. doi:10. 1071/SR9870461

Eivazi F, Tabatabai MA (1977) Phosphatases in soils. Soil Biol Biochem 9:167-172. doi:10.1016/0038-0717(77)90070-0

Eivazi F, Tabatabai MA (1988) Glucosidases and galactosidases in soils. Soil Biol Biochem 20:601-606. doi:10.1016/00380717(88)90141-1

Fierer N, Schimel JP, Holden PA (2003) Variations in microbial community composition through two soil depth profiles. Soil Biol Biochem 35:167-176

Holden SR, Treseder KK (2013) A meta-analysis of soil microbial biomass responses to forest disturbances. Front Microbiol 4:1-17

Horwath WR (2005) The importance of soil organic matter in the fertility of organic production systems, Western Nutrient Management Conference

Jackson ML (1958) Soil chemical analysis. Prentice Hall, Englewood Cliffs

Ladd JN, Butler JHA (1972) Short-term assays of soil proteolytic enzyme activities using proteins and dipeptide derivatives as substrates. Soil Biol Biochem 4:19-30. doi:10.1016/00380717(72)90038-7

Landesman W, Dighton J (2011) Shifts in microbial biomass and the bacteria: fungi ratio occur under field conditions within $3 \mathrm{~h}$ after rainfall. Microb Ecol 62:228-236. doi:10.1007/s00248-0119811-1

Myneni RB, Dong J, Tucker CJ (2001) A large carbon sinks in the woody biomass of Northern forests. Proc Nat Acad Sci USA 98:14784-14789. doi:10.1073/pnas.261555198 
Noguez AM, Escalante AE, Forney LJ, Mendoza MN, Rosas I, Souza V, Oliva FG (2008) Soil aggregates in a tropical deciduous forest: effects on $\mathrm{C}$ and $\mathrm{N}$ dynamics, and microbial communities as determined by t-RFLPs. Biogeochemistry 89:209-220. doi:10. 1007/s10533-008-9214-7

Nsabimana D, Haynes RJ, Wallis FM (2004) Size, activity and catabolic diversity of the soil microbial biomass as affected by land use. Appl Soil Ecol 26:81-92. doi:10.1016/j.apsoil.2003.12. 005

Olsen S, Watanabe FS, Bowman RA (1983) Evaluation of fertilizer phosphate residues by plant uptake and extractable phosphorus. Soil Sci Soc Am J 47:952-958

Paudel S, Sah JP (2003) Physiochemical characteristics of soil in tropical sal (Shorea robusta) forests in eastern Nepal. Himal J Sci 1:107-110

Recous S, Mary B (1990) Microbial immobilization of ammonium and nitrate in cultivated soils. Soil Biol Biochem 22:913-922. doi:10.1016/0038-0717(90)90129-N

Six J, Bossuyt H, Degryze S, Denef K (2004) A history of research on the link between (micro) aggregates, soil biota, and soil organic matter dynamics. Soil Tillage Res 79:7-31. doi:10.1016/j.still. 2004.03.008

Sparling GP, Whale KW, Ramsay AJ (1985) Quantifying the contribution from the soil microbial biomass to the extractable P levels of fresh and air dried soils. Aust J Soil Res 23:613-621. doi:10.1071/SR9850613

Stanford G, Smith SJ (1978) Oxidative release of potentially mineralizable soil nitrogen by acid permanganate extraction. Soil Sci 126:210-218
Stubberfield LCF, Shaw PJA (1990) A comparison of tetrazolium reduction and FDA hydrolysis with other measurements of microbial activity. J Microbiol Methods 12:151-162. doi:10. 1016/0167-7012(90)90026-3

Tripathi N, Singh RS (2013) Cultivation impacts soil microbial dynamics in dry tropical forest ecosystem in India. Acta Ecol Sin 33:344-353. doi:10.1016/j.chnaes.2013.09.009

Vance ED, Brookes PC, Jenkenson DS (1987) An extraction method for measuring soil microbial biomass C. Soil Biol Biochem 19:703-707. doi:10.1016/0038-0717(87)90052-6

Walkley A, Black IA (1934) An examination of the Degtjareff method for determining soil organic matter and a proposed modification of chromic acid titration method. Soil Sci 37:29-38

Wang QK, Wang SL (2007) Soil organic matter under different forest types in Southern China. Geoderma 142:349-356. doi:10.1016/j. geoderma.2007.09.006

Wang CK, Yang JY (2007) Rhizospheric and heterotrophic components of soil respiration in six Chinese temperate forests. Glob Change Biol 13:123-131. doi:10.1111/j.1365-2486.2006.01291.x

Yang K, Zhu J, Zhang M, Yan Q, Sun OJ (2010) Soil microbial biomass carbon and nitrogen in forest ecosystems of Northeast China: a comparison between natural secondary forest and larch plantation. J Plant Ecol 3:175-182. doi:10.1093/jpe/rtq022

Zhao D, Li F, Wang R (2012) Soil inorganic nitrogen and microbial biomass carbon and nitrogen under pine plantations in Zhanggutai sandy soil, China. Acta Ecol Sin 32:144-149. doi:10.1016/S1002-0160(08)60073-9 